\title{
"Fastiginia de Tomé Pinheiro da Veiga. Edición de los días 10 y 28 de junio de 1605: primer documento de la recepción del Quijote"
}

\author{
Aurelio Vargas Díaz-Toledo*
}

Desde su publicación en 1605, el Quijote obtuvo un éxito tan notorio que rápidamente salieron al mercado no sólo nuevas impresiones sino también ediciones piratas que intentaban sacar un provecho comercial de una obra que comenzaba a estar en boca de todo el mundo. Un éxito que se expresó de variadas formas, y una de ellas fue a traves de la aparición de sus personajes en espectáculos populares.

A los pocos meses de su puesta en circulación, don Quijote, Sancho y algunos protagonistas más del libro empezaron a figurar en numerosos acontecimientos, siempre relacionados con fiestas, mascaradas, torneos y demás representaciones de carácter lúdico que no hacían nada más que poner de manifiesto, como nos ha hecho ver Lucía Megías, la manera en que el Quijote fue acogido en un principio, esto es, como un libro de caballerías en donde primaba por encima de todo el entretenimiento ${ }^{2}$. Muchas fueron las apariciones de estos personajes en los años inmediatamente posteriores a la publicación de la primera parte del Quijote, y en todas ellas existía un denominador común: la intención de entretener y hacer reír al público lector y oyente.

Así, en una sortija caballeresca celebrada en 1607 en el pueblo peruano de Pausa, en la provincia de Parinacochas, a raíz de la elección del Marqués de

*. Universidad Complutense de Madrid. Centro de Estudios Cervantinos. ${ }^{1}$

1. El presente trabajo ha contado con la ayuda de una beca de Formación de Personal Investigador de la Comunidad Autónoma de Madrid.

2. Véase en este sentido el fundamental estudio de Lucía Megías, José Manuel: Los primeros ilustradores del "Quijote”, Madrid, Ollero \& Ramos, 2005. 
Montesclaros como Virrey del Perú, ya tenemos un "don Quijote" y un "Sancho Panza" cabalgando con un aire entre jocoso y humorístico que producía "una extraña riza" a quienes los contemplaban ${ }^{3}$. Al margen de esta primera documentación quijotesca en tierras americanas, contamos en Alemania con la primera representación iconográfica de los protagonistas de la inmortal novela de Cervantes; se trata de unas fiestas conmemoradas en Dessau, en 1613, con motivo del bautizo del heredero del principado de Anhalt, el descendiente de Johann Georg, cuyas conmemoraciones se plasmarán por escrito al año siguiente en Leipzig y tendrán a Andreas Bretschneider como el responsable de dibujar el desfile en que intervienen los personajes quijotescos, donde pinta al ilustre hidalgo con un admirable penacho de plumas sobre un morrión y con el cuello de dozavo, imagen muy similar a aquélla de Pausa ${ }^{4}$. El 6 de octubre de 1614 los protagonistas de la obra cumbre cervantina también harán acto de presencia en unas festividades organizadas para la beatificación de Santa Teresa de Jesús en Zaragoza. En ellas aparecerán caracterizados de una forma muy singular: como cazadores de demonios. Pero este fenómeno creciente no termina aquí. A lo largo de las dos primeras décadas desde su lanzamiento editorial, ciudades como Córdoba, Sevilla, Salamanca, Baeza o Utrera verán desfilar sus siluetas por sus calles adoquinadas. Como es notorio, éstas y otras representaciones incidirán en los aspectos más humorísticos de la pareja cervantina, indicando así un ámbito de acogida concreto y unas raíces de corte popular.

Sin embargo, la primera documentación existente hoy día sobre la recepción del Quijote, y de la que nos vamos a ocupar en el presente trabajo, vino a través del portugués Tomé Pinheiro da Veiga (1566, Coimbra- 29 de julio 1656, Lisboa), quien narró en su Fastigínia o fastos extraordinarios sacados de la tumba de Merlín, donde fueron hallados junto a la Demanda del Santo Grial por el arzobispo D. Turpín, descubiertos y sacados a la luz por el famoso lusitano fray Pantaleón, que los encontró en un monasterio de novatos... a costa de Jaimes del Temps Perdut, comprador de libros de caballerías ${ }^{5}$, los acontecimientos acaecidos entre abril y julio de 1605 en la corte vallisoletana. Situémonos en el contexto histórico. Tras la muerte de Felipe II en 1598, subió al trono su hijo Felipe III. El anterior sistema de gobierno, caracterizado por un mayor poder personalizado en manos del monarca, dio paso a una nueva situación política bien diferenciada, en que la figura del valido adquirió un papel fundamental. Y es que ya a finales del siglo XVI Felipe III había de-

3. Una nueva edición de este texto se puede consultar en José Manuel LUCÍA MEGÍAS y Aurelio VARGAS DÍAZ-TOLEDO: "Don Quijote en América: Pausa, 1607 (Facsímil y edición)", en la revista colombiana Literatura: teoría, historia y crítica, $\mathrm{n}^{\circ}$ 7, 2005, pp. 203-244.

4. Una magnífica ilustración de la imagen alemana se puede admirar en: Andreas BRETSCHNEIDER: El ingenioso hidalgo Don Quixote de la Mancha, cavallero de la triste figura (Leipzig, Henning Gross, 1614), Centro de Estudios Cervantinos y Armero Exposiciones y Ediciones, 2005.

5. El título original portugués es el siguiente: Fastigínia ou fastos geniaes, tirados da tumba de Merlim onde forão achados com a Demanda do Sancto Grial pelo Arcebispo D. Turpim, descubertos e tirados à luz pelo famoso lusitano frei Pantaleão, que os achou em hum mosteiro de calouros...a custa de Jaimes de Temps Perdut, comprador de livros de cavalarias. 
legado su poder en manos del ambicioso Duque de Lerma, un personaje cuyos objetivos primordiales serán el enriquecimiento personal y el desarrollo de un nepotismo que minarán la ya maltrecha situación económica del momento. Será el mismo Francisco de Sandoval y Rojas quien proceda al traslado de la corte de la Monarquía Hispánica de Madrid a Valladolid, durante un intervalo de tiempo comprendido entre 1601 y febrero de 1606, con la única intención de atraer para sí al rey español y separarlo de otras influencias capaces de impedir sus planes personales. A su materialización ayudaron sobremanera otros consejeros reales como Rodrigo Calderón y Pedro Franqueza.

Pues bien, será en este Valladolid donde la nieta del emperador Francisco I, Margarita de Austria, que había casado en 1599 con Felipe III, dé a luz a Felipe Dominico, el primogénito de la Casa de Austria y futuro Felipe IV. Su nacimiento tuvo lugar el viernes de la Semana Santa de 1605, día 8 de abril, con motivo del cual se conmemoraron en dicha ciudad una sucesión ininterrumpida de fiestas, juegos, corridas de toros y todo tipo de celebraciones que sólo finalizaron bien entrado el mes de junio. Y para todo lo sucedido, como hemos dicho, contamos con un cronista de excepción. Nos referimos a Pinheiro da Veiga, que, según manifiesta a lo largo de su obra, permaneció en Valladolid en torno a ocho meses, desde diciembre de 1604 hasta el 26 de julio del año siguiente, de modo que conoció de buena mano los tejemanejes de uno de los centros de poder más importantes de Europa. Dispuesto a describir hasta el más mínimo detalle, el autor conimbricense da comienzo a su Fastiginia en la Pascua de 1605, unos días antes de tener lugar el feliz acontecimiento, y articula su obra en tres partes: la Philipstrea, sobre las fiestas realizadas en honor del nacimiento de Felipe IV; la Pratología o Baratillo cotidiano, acerca del trato, buena conversación y desenvoltura de las damas; y la Pincigrafía o "descripción e historia natural y moral de la corte vallisoletana". Además, encontramos diseminados por todo el texto variados comentarios sobre las paces habidas entre Inglaterra y España, sobre la situación política del momento y otras descripciones tocantes al bautizo del príncipe, a la procesión del Corpus $C h$ risti o a los vestidos y libreas de cada uno de los asistentes a estos actos.

La Fastiginia, cuya redacción se realizó originalmente en portugués en 1605 -aunque con añadidos datados en 1607 y 1620-, no sólo tuvo una difusión manuscrita, sino que además se transmitió de una manera anónima bajo el seudónimo de "Turpín”, el archiconocido arzobispo de Reims. Para explicar este último hecho baste sólo añadir que, aparte de las alusiones sarcásticas al entorno del Duque de Lerma, cuando se produjo la lucha por la independencia de Portugal en 1640, Tomé Pinheiro da Veiga, sin pensárselo, se inclinó hacia el bando del Duque de Braganza.

Sin embargo, de esta crónica cortesana a nosotros nos interesa lo acaecido los días 10 y 28 de junio, sobre los cuales hemos elaborado la presente edición del texto portugués y su correspondiente traducción al castellano. En el primero de ellos se describen unas fiestas de cañas y toros que, en un principio, estaban destinadas para el día 6 del mismo mes, cuyo aplazamiento se debió a que todavía no habían llegado a la corte muchos de los caballos que iban a par- 
ticipar en el cortejo y a que las marlotas -especie de vestiduras moriscas- aún no estaban confeccionadas. Durante esta jornada desfila ante nuestros ojos esa primera imagen de don Quijote y Sancho, una representación que guarda múltiples conexiones con un carnaval. Vemos al hidalgo manchego vestido de una manera extravagante, con un sombrero grande en la cabeza y sobre una cabalgadura a la que espolea sin conseguir que fuese más aprisa. Delante de él caminaba su fiel escudero, con la barba alzada, con unos anteojos y en el pecho la insignia de la orden portuguesa de Cristo, todo ello para darle un aire de mayor autoridad y que, en ciertos aspectos, está alejado de aquel otro retrato pintado por Cervantes en sus páginas maestras.

El 28 de junio ambos personajes son representados una vez más, poniendo de manifiesto de nuevo el enorme éxito de que gozó el Quijote tras su salida a la plaza pública. En esta ocasión se vio la "más notable farsa y figura que podía haber", esto es, un don Quijote muy maltratado, tremendamente descuidado, largo de talle y haciendo las veces de un galán enamoradizo que cortejaba, arrodillado, a unas damas. Ante las burlas y pullas de más de dos centenares de curiosos que habían sido convocados por dos bellacos, sólo un alguacil, avisado por parte de un corregidor, hizo disgregar a la gente, y es que "la grita y risas eran de suerte que no había quien se escuchase".

Sirva esta nueva versión de un texto riquísimo en detalles sobre el ambiente cortesano de Felipe III, para volver la vista atrás y comprobar no sólo la manera en que el texto cervantino fue acogido por sus contemporáneos, sino también el modo en que fue leído e interpretado desde su publicación.

\section{SOBRE LA EDICIÓN DEL TEXTO PORTUGUÉS Y NUESTRA TRADUCCIÓN AL ESPAÑOL}

El texto portugués se ha completado con una serie de notas aclaratorias, todas ellas sobre los personajes históricos citados en el mismo para que el lector pueda situarlos de una manera inmediata en su contexto.

Para la realización de esta nueva edición hemos consultado hasta cuatro testimonios de los doce que han transmitido la Fastiginia ${ }^{6}$, los dos de la Biblioteca Pública de Évora (Cód. CV/1-30, d; y Cód. CV/1-31, d) y los conservados en la Nacional de Lisboa (cód. 349: de 134 fols.) y en la Real Academia de la Lengua Española de Madrid $^{7}$ (RM-77). Otros manuscritos de la

6. De cualquier forma pensamos que aún es posible que en un futuro se localicen nuevos ejemplares, sobre todo, en bibliotecas portuguesas.

7. Agradecemos a José Manuel Lucía Megías el redescubrimiento de este manuscrito, cuya breve descripción codicológica sería la siguiente: posee el ex-libris de Álvaro Virgilio de Franco Teixeira ("Boni libri, boni amici"), 204 fols. (302 x 208 mm.), letra del siglo XVII, escrito a línea tirada por una misma mano, encuadernación en piel gofrada con hierros dorados. Perteneció al legado Rodríguez Moñino-María Brey. Alberga además una Relación de los amores entre el conde de Villamediana y la marquesa del Valle, y una encamisada. 
obra se encuentran en: Academia das Ciências de Lisboa (Azul, ms. 70), Biblioteca Geral da Universidade de Coimbra (Ms. 3099: con letra del siglo XIX), Bibliothèque Nationale de Paris (Fonds portugais, ms. 114), British Library de Londres. También existen noticias de copias personales tanto de José Pereira de Sampaio como de Aníbal Fernandez Thomaz, que bien pudieran tratarse de alguno de los códices mencionados con anterioridad. Al mismo tiempo, hemos tenido en cuenta no sólo la edición impresa del propio Pereira de Sampaio hecha a partir de los dos manuscritos de la Biblioteca Pública Municipal do Porto (ms. 503 [1:193] y ms. 504 [1:197]), sino también la traducción llevada a cabo por Pascual de Gayangos en base al ejemplar de Londres. En todos ellos figuran los episodios de don Quijote y Sancho, aunque hay que dejar constancia del hecho de que algunos códices amplían otros episodios y suponen, por lo tanto, una versión más tardía de la obra, como hemos dicho unas líneas más arriba, con añadidos fechados entre 1607 y 1620. La traducción castellana ha sido realizada a partir de nuestra versión portuguesa.

\section{EDICIÓN DEL TEXTO PORTUGUÉS}

10 de Junho. Festa de canas e touros pelo nascimento do Príncepe.

Expectata dies aderat $^{8}$, porque aos 10 de Junho, sexta-feira, se fes a principal festa de canas e toiros, para o que os inglezes estavam mui alvoraçados por serem festas que lá não uzam.

Recolheram-se pela menhã dezasseis toiros com muitos cavaleiros, que os vão esperar huma légua e vêm fazendo sorte, que hé huma meia festa.

Cobrio-se toda a prassa de area miúda, quatro dedos em alto, com o que ficou como a palma da mão, principalmente depois de aguada e empapada em água, o que fazem mui em breve e com mui boa invenção, porque põem dezasseis carros em ordem, com suas pipas e nos tornos duas mangas de couro e, meneando-as, vão aguando e os carros correndo, com o que em menos de três credos fica regada e fresca a praça; e isto fazem por muitas vezes.

Hé a praça a mais fermoza que tem Valhadolid, como tenho dito, toda de colunas ao redor, mui grossas, de 185 passos de comprido e de huma só pessa, com seus capitéis ensima, e tem balcões em baixo, e por sima varanda de vinte e nove arcos na fronteira, que hé fermosíssima casa.

Armaram agora o palanque desde a primeira janela até o chão, com o que ficou a praça mais apanhada e mais fermoza e os palanques seguríssimos, e caberiam neles dez [e] até doze mil pessoas.

Tem a praça três ordens de janelas nos três sobrados, e em cada ordem há cem janelas, e sobre elas eirados com seu corrimão, que tomam toda a largura

8. Virgilio, Eneida, V, 104: Y había llegado el día tan esperado. La traducción es nuestra. 
da primeira caza, e detrás dela dez com muitas janelas sobre o eirado, que são duzentas janelinhas. E como todas são por huma ordem e correspondência e a frontaria toda do mesmo lavor do tijolo, fica fermosíssima, e fes-se toda por huma traça, porque se queimou a quarta parte da cidade ${ }^{9}$ e quando se reedificou em tempo del-Rey velho, se ordenou e trassou toda por uma maneira, guardando a mesma semetria em toda a praça e mais ruas que se fizeram.

Estavam todos estes lugares ocupados e os tilhados se destilharam, e estava a gente em pinha sobre eles. Entram na praça vinte e quatro ruas e nelas se fizeram tablados de dous sobrados que as ocupavam. Fizemos compu $<\mathrm{n}>$ tação da gente que podia estar assentada e achamos que seriam mais de quarenta mil pessoas, e, com haver tanto lugar, nos custou lugar para ambos duzentos reales, mas valiam mil e oitocentos os ordinários; e assim, quando os donos alugam estas cazas rezervam para si estes dias, que lhes rendem mais que todo o aluguer do ano; e, ainda que as dão aos Alcaldes de Corte, paga-se a metade.

Às onze estavam já todos os lugares ocupados nesta forma: as janelas quazi todas se tomaram para os Conselheiros; deram os arcos de sima e os de baixo do concistório aos inglezes principaes; e aos demais deram os tablados, que escolheram nos palanques das ruas senhoraços que os fizeram; e as janelas quazi todas se largam a mulheres, que nenhuma perde ocazião de folgar nestas conjunções, todas riquíssimamente vestidas; as janelas muito enfeitadas no pouco e pequeno lugar que há entre humas e outras.

Quando El-Rey vê as festas, tem seu docel e nenhuma outra pessoa o pode ter, nem chapéo de sol, nem couza alguma por sima de seda, e assim fizeram uns toldosinhos por sima de estopa sobre elas contra o sol e com velas os eirados.

Às onze vieram as trombetas, atabales e chamarelas da cidade, que foram vinte e quatro, de telilha de tela falça sobre tafetá encarnado, sombreiros e bandeiras e mangas dos atabales do mesmo, que se repartiram nos quatro cantos da praça, onde tinham seus palanques.

Perto das doze entraram os reis que haviam de jantar no concistório com muito aparato, e foi desta maneira: entraram logo alguns coches e carroças de mulheres dos grandes e senhoras que haviam de estar com a Rainha, porque ela e as suas damas vinham em facas. Seguiam-se vinte pages del-Rei a pé; após eles os titulares e senhores da corte, que eram oitenta, e vinte e cinco que vinham detrás com as damas, vestidos admiravelmente de brocados e com toda a riqueza que se pode imaginar, carregados de ouro, pérolas e pedras; nas cadeas botões e cintilhos, que para este dia rezervaram o melhor. E como fazia grande calma e sol, cegavam a gente os raios que sahiam das pedras e medalhas, que todo o bom de Espanha hia neles e nas damas.

E nesta universal holgança, por não faltar entremês, apareceo hum D. Quixote que hia nos dianteiros como aventureiro, só e sem companhia, com hum

9. Se refiere al incendio que tuvo lugar en Valladolid en 1561, a consecuencia del cual el rey Felipe II llevó a cabo la reconstrucción y rehabilitación de gran parte de la ciudad, sobre todo de la Plaza Mayor, de Platerías y de la Plaza del Ochavo. 
chapéo grande na sua cabeça e huma capa de baeta e mangas do mesmo, huns calções de veludo e humas boas botas com esporas de bico de pardal, batendo las ijadas a hum pobre quartão ruço com huma matadura no fio do lombo, das guarnições do coche, e huma cela de cocheiro; e Sancho Panço [sic], seu escudeiro, diante. Levava huns óculos por autoridade e bem postos, e a barba alçada, e na meta[de] do peito hum Hábito de Cristo; e como hia só e naquela figura, começaram a nos perguntar humas vizinhas se era o Embaixador de Portugal ou que couza era aquela. Se mi dimanda alcun chi costui sia ${ }^{10}$ direi que era o Sr. Jorge de Lima Barreto, que por honra de Portugal reprehendeo de maos cortezãos os mais senhores portuguezes e quis acompanhar o seu Rei com esta libré, e tomou hum cavalo do seu coche que não queria dar passada:

di cento punte l'asinello offese, né di sua tardità però lo tolle. ${ }^{11}$

E por estas e outras taes somos opróbrio das gentes e desprezo dos castilhanos. Tornando à história, após os fidalgos hiam os meninos da Rainha a cavalo; seguiam-se os grandes todos que estão na corte, que são os que contei, e os principaes com os vestidos que despois direi; despois os escudeiros da câmara e lacaios del-Rei e da Rainha diante dela e del-Rei. Vinha a Rainha em huma hacanea branca fermosíssima, em hum silhão de prata dourada e esmaltado, com algumas pedras engastadas, com gualdrapa de veludo negro, bordado todo de lacárcias de ouro e prata e canutilho de ouro e guarnições do mesmo, e ela em saia larga ou cota de cavalgar, de tela de ouro roxa, com bordadura de aljófar. À sua ilharga, El-Rei de libré e cores da Rainha, capa, gorra e roupeta negra, calsas vermelhas, forros brancos e plumas das mesmas cores; detrás da Rainha a camareira-mor e outras duas damas em andilhas com gualdrapas de dó. Logo quinze damas da Rainha em mui fermozos palafrens em silhões de prata, gualdrapas de veludo, com passamanes de ouro ou bordado de canutilho e rozas; pelo meio, de ouro e prata -que nunca Oriana em seu tempo com mais grandeza provou o Arco de los Leales Amadores, ainda que levava consigo a senhora D. Brides e a senhora Dulcenia [sic] del Tobozo-, e tudo era necessário para passarem as caras falças das damas, que parece que escolheram huma e huma, se não hé tal e tal. Vinham vestidas com muita riqueza, de diferentes cores, mas todas de cotas largas golpeadas com suas moscas de ouro e prata miúdas, e as mais bordadas em lugar das guarnições. Hiam mais duas meninas da infanta, huma delas muito fermoza; levavam-nas de rédea lacaios da Rainha, e com cada hum hiam hum ou dous galantes como Anjos da Guarda.

10. Orlando Furioso: C. I, oct. 45: Se mi domanda alcun chi costui sia. Trad. de José María Micó, pp. 20-21: Si alguno me pregunta quién es este.

11. Orlando Furioso: C. VIII, oct. 31: di cento punte l'asinello offese,/ né di sua tardità però lo tolle. Trad. de José María Micó, pp. 248-249: espoleó con frenesí al pollino,/ sin conseguir que fuese más deprisa. 
Chegando ao concistório, desceo à Rainha o seu mordomo-mor; às damas, seus irmãos ou parentes que as acompanhavam, ou os fidalgos velhos, mordomos e guarda-damas e outros, como hé custume. A El-Rei tomou o estribo o Duque de Lerma ${ }^{12}$ como estribeiro-mor. Foi esta entrada das couzas que mais folguei de ver pelo descostume de ver entrar as damas a cavalo e com tanto concerto e magestade. E assim, destas festas os acessórios foram o mais principal, como torneo que não tem que ver mais que as entradas.

Os que mais galantes sahiram nestes dias foram os príncepes, que, por razão de luto que traziam por morte do irmão e festa do príncepe, sahiram de negro e prata, a saber: bordado de tela de prata e canutilho dela sobre veludo negro, os lavores mui descubertos e relevados, à maneira dos guadamecins negros dourados, mas as rozas miúdas, capas, calsas, roupetas, gualdrapas e guarnições, tudo de huma sorte que sahia e lustrava muito mais que todas as couzas.

O segundo, o Duque de $\mathrm{Alva}^{13}$, de outro vestido e gualdrapa, bordado de ouro sobre azul, tão custoso e rico como os primeiros.

O terceiro, D. João de Tassis ${ }^{14}$, com outro tercero vestido e gualdrapa de bordado miúdo de tela de prata ou telilha que lustrava muito, onde se descobria da folhagem de ouro que a cobria com humas rosas ou flores levantadas com muita argentaria, e principalmente no capelo e coura e bordadura, entreçachadas pessas e botões de diamantes na obra do bordado.

O quarto, o Marquês del Valle ${ }^{15}$, de chamalote de ouro azul com doze passamanes ou debruns de tela perfilada, calsas de canutilho, gualdrapas azúis, com tantos passamanes de ouro que quazi a cobriam, e os forros de tela.

$\mathrm{O}$ quinto, o filho de Franquera ${ }^{16}$, à gineta, porque tem os melhores trinta $\mathrm{e}$ dois cavalos que há na corte, e o adereço de aljófar e pedras ou pérolas, riquíssimo, e ele de chamalote de ouro roxo, com doze debruns acairelados de brocado, colete e calsas de canutilho e com infi[ni]dade de jóias e diamantes.

Comeram os reis no concistório em público e serviram-nos as damas à cea.

À huma entrou o Prezidente do Conselho Real, o Conde de Miranda ${ }^{17}$, com esta magestade: levava diante vinte e sete Alguazis mui bem trajados, e em

12. El Duque de Lerma es Francisco de Sandoval y Rojas. Casó en Madrid en 1576 con doña Catalina de la Cerda, camarera mayor de la reina doña Margarita de Austria.

13. Antonio Álvarez de Toledo (1568-1639), V Duque de Alba y de la Llave dorada, casó con Mencía de Mendoza.

14. Juan de Tassis y Peralta (Lisboa, 1582- Madrid, 1622), Conde de Villamediana, correo mayor de Felipe III.

15. Marqués del Valle de Oaxaca. Nieto de Hernán Cortés.

16. El padre del personaje mencionado aquí es Pedro Franqueza y Esteve (¿1547?-d. 1612). Fue conde de Villalonga. Inició su carrera al servicio del Marqués de Denia, después Duque de Lerma. Hacia 1600 se convirtió en Secretario de Estado para los asuntos de Italia (fue Correo Mayor de Nápoles). En 1603 fue secretario de Hacienda y en 1604 uno de los artífices de la concesión de miles de ducados por parte de las cortes valencianas. Tras recibir una enorme cantidad de dinero por parte de los madrileños, fue uno de los responsables de que la corte volviera a Madrid. Según se desprende a lo largo de Fastiginia, su hijo al que se hace alusión aquí podría ser Francisco Franqueza.

17. Diego de Zúñiga Avellaneda Bazán y Cárdenas, Conde de Miranda en estas fechas, era el consuegro del Duque de Lerma. Fue también designado Presidente del Consejo de Castilla. 
mui fermozos ginetes quatro Alcaldes da Corte, o Corregedor de Valhadolid, quinze Ouvidores do Conselho Real; levava sempre detrás de si, por estado, coche, andas e cadeira. Este hé mui soberbaço e inchado, assim no espírito como no corpo, consogro do Duque de Lerma, e este ofício hé a segunda pessoa despois del-Rei.

Às duas entrou a guarda dos Alabardeiros em fileiras, que pareceo muito bem, e comessaram a despejar a gente da praça, fazendo-a sahir, no que houve muito trabalho. Ficando despejada, a auguaram com os carros e ficou fermozíssima, ocupando-se as janelas todas, de sorte que em cada huma estavam dezasseis ou vinte pessoas.

Às três sahio El-Rei e logo a Rainha, a qual foi buscar o Almirante Embaixador, que já lá estava.

Tem o concistório dezanove arcos: no do meio ficam os reis, e ao duque disse o Rei: sede a dextris meis; e assim estava cuberto no mesmo arco e balcão, mandando os Alguazis dali, e nenhuma outra pessoa, porque os mais grandes ficaram detrás das cadeiras; nos dous arcos da mão direita os príncepes com os seus criados detrás, e nos outros os inglezes principaes. As damas tinham os nove arcos da mão esquerda, e por mais honra se deo lugar entre elas ao Almirante, que soube escolher o melhor, que é a infanta D. Catarina de la $\mathrm{Cerda}^{18}$, a quem deu huma jóia de muito preço.

Estando a praça neste estado e os assentos ocupados nesta forma, com muito alvoroço e estrondo dos instromentos que estavam em seus palanques, entraram alguns toureiros: o primeiro, D. Vicente Zapata ${ }^{19}$, com oito lacaios de calsas e gibões de leonado e guarnição amarela, coura branca, tudo acutilado e forrado de telilha de prata que se descobre pelos golpes, e estas couras brancas sacam todos os lacaios.

Logo oito titulares, que foram o Duque de Alva, o Marquês de Serralva ${ }^{20}$, o de Barcarrota ${ }^{21}$, o de Curunha ${ }^{22}$, o de Ayala ${ }^{23}$, D. António de Toledo ${ }^{24}$, o de Távora $^{25}$, o Conde de Salinas ${ }^{26}$. Despois foram entrando outros fidalgos e senhores com diversas livrés. Os primeiros, vinte e quatro lacaios de roxo e vermelho golpeado, com seus entre forros de velilho ou telilhas, couras

18. Catalina de la Cerda, Marquesa de Denia y Camarera Mayor de la reina Margarita de Austria. Al casar con Francisco Sandoval y Rojas se convirtió en Duquesa de Lerma.

19. Vicente Zapata, señor de la Llave.

20. Probablemente se refiera al III Marqués de Cerralbo, Rodrigo Pacheco y Toledo Colonna.

21. Alonso de Portocarrero, Marqués de Villanueva de Barcarrota.

22. Según se cuenta en lo sucedido los días 1 y 2 de junio, entre los asistentes se contaba el Conde de Coruña y no el Marqués de la misma localidad. El Conde de Coruña en estas fechas era Lorenzo Suárez de Mendoza, VI Conde de Coruña, Vizconde de Torija.

23. Según se narra los días 1 y 2 de junio, entre los asistentes estaba el Conde de Ayala y no el Marqués de Ayala.

24. Parece hacer alusión a D. Antonio de Toledo, gran prior de la orden de San Juan y primo del Duque de Alba.

25. Parece referirse al Marqués de Távara, Enrique de Pimentel.

26. Diego de Silva, Conde de Salinas y Rivadeo, hijo de Ruy Gómez de Silva. A la muerte de Juan de Borja en 1606, formó parte del Consejo de Portugal. 
brancas. Outros doze lacaios de negro e branco com passamanes de prata; outros seis de negro, mangas e forros brancos; outros seis de vermelho e roxo, outros três de leonado e branco, outros oito de leonado e amarelo, outros seis de roxo e branco, todos de tafetá, chapéos quarteados das mesmas com plumas e os passamanes de ouro e prata falsa, e os forros de velilhas de prata, de cores, e todos com seus rojões. Estes vestidos não servem mais que este dia e, se ao outro há outros toiros, hão-de tirar outros e não os mesmos, e assim se vendem logo de graça.

O que melhor o fes foi o Marquês de Barcarrota, que quebrou alguns rojões destimidamente. Também sucedeo bem a D. Pedro de Barros ${ }^{27}$, que meteo hum garrochão a hum toiro de sorte, pelo cachaço, que lhe passou as goelas e se vaz[i]ou em sangue pela boca e cahio logo a poucos passos.

Ao Duque de Alva, querendo acudir, matou, em entrando, o toiro hum cavalo, que lhe saíram as tripas e lhe custou mil cruzados poucos dias antes.

Mataram outros dous cavalos sem suceder couza notável, porque logo matam os toiros ou com garrochões ou às cutiladas os mesmos de cavalo, que, como doudos, os cercam e despedaçam com os trassados pelos rostros e cadeiras aos pobres bóis, que todos os levam mortos os ganapães e alguns ficam aos cães.

Vieram também a lanciar o toiro dous fidalgos de fora, pouco conhecidos pelo nome e menos pelas obras, hum deles chamado Martim Leal, que o não foi em esperar o toiro com os olhos do cavalo tapados. E hindo o coitado passando lhe meteu à traição a lança pelas ilhargas, e correndo o toiro lha levou da mão sã e salva levantada no ar como garrocha e morreo dahí a pouco. Tornou a esperar outro e, como era negro, não assertou o alvo e não fes nada. O companheiro o fes menos mal, que o esperou de rostro a rostro e, ainda que deu a lançada adiante da crus, contudo se desviou bem, quebrando a lança, e o toiro morreo dahí a pouco.

Já outra ves vi dar estas lançadas a toiros a D. Hierónimo de Aiansa e dar grandes forças com huma lança com huma antena, e não fes nada; e pouco mais outro fidalgo que então sahio, e hé temeridade parva.

Melhor andou D. Gonçalo Chacón ${ }^{28}$ da outra ves que cá estive, que dizendo El-Rei à cea que folgara de ver correr huns toiros, ao outro dia se andavam correndo defronte de palácio, às três, com mui fermozos palanques. E esperando D. Gonçalo Chacón hum toiro com huma lança, lhe acertou pela cruz e o atravessou de sorte que voltou com a barriga para o ar diante do cavalo.

E aos des deste, em Medina del Campo, me contaram que, esperando hum pecador o toiro, se lhe espantou o cavalo ouvindo-o vir, e deu com ele de costas na area; e tornando a vir no mesmo cavalo medroso, deu na testa ao

27. Pedro de Barros o Barrios parece ser el hijo de Cristóbal de Barrios, que aparece mencionado también a lo largo de Fastiginia.

28. Gonzalo Chacón, nombrado Caballerizo Mayor en 1585, se convirtió más tarde en Conde de Casarrubios. 
toiro, e empinando-se-lhe o cavalo tornou a dar com as costilhas na area, e está o pecador acabando de disgosto.

Tornando aos nossos touros, às seis eram corridos doze ou treze, e porque comessava a sombra, se foi el-Rei e o duque vestir de suas librés para as canas, que foi huma das mais soberbas festas que dizem se fes em Espanha.

Em sahindo El-Rei, se despejou a praça fasendo assentar no chão algumas pessoas que ficaram. Logo entraram vinte e quatro carros enramados com bandeiras das cores da cidade, que pareciam grandes árvores. E sahindo em ala, aguaram a praça, acodindo a gente a tomá-la em chapéos <e > nas cabeças, que se estavam abrazando; e foi outra nova festa, que parecia a praça montanha, tornando-se a despejar.

Entraram na praça doze atabaleiros, eles e as cobertas dos cavalos de tafetá encarnado e forros roxos a duas barras, de passamanes de prata, eles de roupas rozagantes destas duas cores, sombreiros, mangas dos atabales e tudo mais debaixo de velilho, de prata.

Logo vinte e quatro trombetas, todas à gineta, com guarnições, caprazões e girões dos cavalos e bandeiras das trombetas todas da mesma sorte, e todos vinham em facas del-Rei, mui fermosas e de muito presso e bem guarnecidas.

Seguiam-se doze azémulas del-Rei com canas por sima, reposteiros de veludo carmezi bordados à redonda, de ouro e prata, de despojos e troféos e no meio as armas reaes ordinárias, de broslado, com suas cores e com a coroa imperial. As alabardas, cordas, sobrecargas, cabestros e silhas, tudo de seda e retrós, e o mesmo nos peitoraes, com franjas até os joelhos de carmezi e branco, os cordões dos rabos das fitas de Colónia em massos, arrochos e pranchas das testeiras de prata mocissa, com as armas reaes, plumas nas cabeças e ancas, grandíssimas, das mesmas cores.

Levavam os azeméis as cores e trages dos trombetas, mas eram de veludo carmesi, com passamanes e morenilhos de prata fina. Após eles dezasseis oficiaes de cavalheriças, como forrieis, guarda-arnezes, mestres dos pages e outros, todos descubertos e vestidos de negro, com suas cadeas de ouro. Logo os pages del-Rei a pé, com suas librés ordinárias de negro.

Entraram logo vinte e seis cavalos del-Rei com seus adereços e jaezes de gineta, quais se pode imaginar, e por sima seus telizes, que são cubertas grandes, como gualdrapas sobre as selas, que os tomam todos até o chão, do mesmo cabelo carmezi com sua bordadura ao redor de ouro; e no meio, em lugar de armas, huma cifra do nome de Phelipus tertius, de ouro, e ramos de laçaria que o tomavam todo, e em sima coroa de prata serrada, com que ficavam lustrosíssimos. Levavam-nos vinte e seis lacaios de calças e roupetas de nácar, com rendas de ouro, tudo golpeado sobre telilha de prata, sendaes azúes com pontas de ouro, sapatos de veludo branco, forros da mesma cor além da telilha.

Seguiam-se os cavalos dos príncepes à destra. Vinham diante quatro lacaios de negro e prata, forros e mangas de telilha com duas adargas com barras prateadas em campo negro; logo os seus doze pages a pé, de sua libré. 
Entraram logo quatro cavalos do príncepe menor com os telizes de veludo negro com pontas redondas ou ondadas em baixo, todos bordados de canutilho de prata riquíssimamente. Os outros oito, para o número doze, se não puderam acabar a tempo que pudessem entrar. Após eles vinham doze cavalos do Príncepe Víctor Amadeo ${ }^{29}$, do mesmo veludo negro e a orla de prata de canutilho e escarchada, e o corpo dos telizes semeado de estrelas de prata, com o que pareciam melhor que todos com serem do mesmo custo; levavam-nos oito lacaios da mesma libré que os quatro primeiros.

Entraram mais seis cavalos enjaezados com adargas brancas e barras de ouro que levavam lacaios del-Rei, e por ser tarde não entraram os mais.

Seguiam-se vinte e um cavalos enjaezados que levavam outros tantos lacaios de verde e prata, gibões brancos de telilha e morenilhos de prata, calças todas apassamanadas de prata, meias verdes, sapatos brancos, plumas e chapéos das mesmas cores, e eram do Condestable e sua quadrilha, que esta foi a sua libré.

Havia mais outros cavalos, que eram hum número infinito o que estava para entrar das outras quadrilhas, e com haver os lacaios todos de librés e eles com jaezes de aljófar e outras invenções, não puderam entrar porque faltava dia, e fizeram sahir os que hiam entrando pela parte esquerda, onde estava a Rainha, e voltaram pela outra.

É certo que ver a praça desta maneira era o mais fermozo espectáculo que se pode imaginar, e foi desgraça começarem tão tarde por temor da calma.

Entraram logo as quadrilhas, que eram oito, correndo às parelhas dous e dous, cada quadrilha sobre si com suas cores diferentes, como logo direi. Em cada quadrilha havia dez e vinham a ser oitenta, e eram quadrilheros os seguintes:

$\begin{array}{ll}\text { El-Rey e sua libré, de nácar } & 1 \\ \text { O Duque do Infantado }^{30} \text {, vermelho e branco } & 2 \\ \text { O Duque de Alva, vermelho e azul }_{\text {O de Pestana }^{31} \text {, azul e branco }} & 3 \\ \text { O Conde de Alva de Lista }^{32} \text {, amarelo e azul } & 4 \\ \text { A cidade, de branco e negro } & 5 \\ \text { O Condestable }^{33} & 6 \\ \text { Os príncepes, de negro e branco } & 7\end{array}$

Eram as librés de setim bordado e forro de telilha nas marlotas ou vaqueiros, com mantos ou capas a modo de mantilhas à romana, tomados no

29. Victorio Amadeo, Príncipe de Saboya, que a esta altura tenía 19 años, como se dice en Fastiginia.

30. Juan Hurtado de Mendoza de la Vega y Luna, VI Duque del Infantado, del Consejo de Estado y Llave dorada.

31. Parece referirse al Duque de Pastrana, Ruy Gómez de Silva.

32. Antonio de Toledo Enríquez, VI Conde de Alba de Liste.

33. Juan Fernández de Velasco y Guzmán, V Duque de Frías, Condestable de Castilla y Presidente de Guerra. 
hombro esquerdo, do mesmo setim bordado de tela falsa em ramos, troncos e diversas folhagens e lavores, tomadas com troçaes de prata e ouro, com canudos de prata batida relevada, e outros modos e invenções em cada quadrilha.

As ordinárias eram falsas, mas alguns senhores as mandaram fazer de tela e prata fina, que valiam muito dinheiro. Os toucados, de diversas invenções, à turquesca e mourisca, todos atrocelados de prata, ouro e aljófar e outras turquilhas, emaranhadas sobre barretes de cores com tranças bordadas e bicos como de diamantes, pontas e botões e medalhas de ouro e pedraria, e para sima caraminholas grandes com seus martinetes e outras plumas; os cavalos com cubertas, borlas e girões da mesma obra, calças e mangas a arbítrio de cada hum.

Entrou El-Rei correndo com o duque em dous cavalos brancos, com muita graça e ar; logo os outros oito de sua camarada, que foram o Duque de $\mathrm{Cea}^{34}$, o Conde de $\operatorname{Lemos}^{35}$, o Marquês de S. Germão ${ }^{36}$, o Conde de Gelves ${ }^{37}$, o de Magalde $^{38}$, D. Pedro de Castro ${ }^{39}$, D. Garcia de Figueiroa ${ }^{40}$, D. Martim de Aragan $^{41}$. Logo o condestable com os de sua quadrilha, e a derradeira a dos príncepes, e eles detrás de todos, que pareceo muito bem porque os faziam lustrar os bons cavalos em que vinham e a fermozura das cores que hiam descubrindo. El-Rei e o duque o fizeram melhor e com mais ar que todos, e os príncepes, assim como foram derradeiros, mereceram o lugar. Foram despois correndo pela parte da Rainha, a terceira carreira pela outra banda e a quarta pelo meio contra a porta por onde entraram, despois de canto a canto em cruz e ficaram repartidos em duas partes, guiando El-Rei huma e o condestable outra. Em fieira foram tecendo huma maranha, atravessando huma fieira junto a outra e fazendo seu meio caracol sem se embaraçarem, que pareceo mui bem, e se foram a tomar outros cavalos, e ficou a praça pequena para eles, com ter 185 passos, que são varas de cinco palmos.

Tornaram a entrar repartidos em quatro quadrilhas, embebendo duas em cada huma, que tomaram as adargas de quatro devizas somente. Não correm as canas como nós, mas vão sahindo em tropa os de hum canto e acometem os daquela banda e logo voltam pelos do outro canto, e esses em tropa os vão seguindo até o seu lugar e voltam pelos da outra parte que os seguem, des fogindo e des seguindo, e assim continuam as canas.

34. Cristóbal Gómez de Sandoval y Rojas, Duque de Cea y posterior Duque de Uceda. Era hijo del Duque de Lerma y de Catalina de la Cerda.

35. Pedro Fernández de Castro, Conde de Lemos, Marqués de Sarria y Presidente de Indias. Hijo del Duque de Lerma y sobrino del Duque de Alba.

36. Juan de Mendoza, Marqués de San Germán.

37. Fernando de Castro y Sandoval, Conde de Gelves y Llave dorada.

38. Juan de Borja, I Conde de Ficalho y de Mayalde. Mayordomo Mayor de la emperatriz María. Aunque en el texto, en los días 1 y 2 de junio, se dice que era Jerónimo de Borja.

39. Pedro de Castro, señor de la Llave dorada. Tío del Conde de Lemos.

40. García de Toledo y Figueroa, gentilhombre de la Cámara del Rey. Señor de la Llave dorada.

41. Con Martín de Aragón parece referirse al Duque de Villahermosa. 
Entre todos andou mais airoso El-Rei, seguro na sela e com tanto ar na cana e adarga que naturaes e estrangeiros, sem exceção de pessoa, lhe deram o primeiro lugar, e a mim me pareceo o mesmo, e a todos nos deu muito contentamento, porque El-Rei a pé não mostra tanto, e a cavalo ou dançando, parece em extremo bem; e o mesmo quererá Deus que seja nas couzas deveras, o que eu não sei, porque as não vi.

Serrou-se nisto a noite, faltando o dia e não festa, que os cavalos do sol, envejozos dos ginetes de Hespanha, não hé muito se apressacem.

Foi a entrada, assim pelo aparato como por rezão do lugar e conjunção em que se fes, huma das grandiozas festas que se fizeram em Hespanha, porque naquela praça, pela igualdade e fermosura dela, estando tão fresca e bem ornada, lustra muito mais; e juntamente por verem o gosto que têm os naturaes de verem os estrangeiros aquilo em que se aventajam às outras nações, fas receber mais contentamento destas grandezas e parecer tudo mais bem assombrado; e sem falta se espantaram os inglezes muito delas.

Foi-se El-Rei vestir camiza a casa do Marquês de Laguna ${ }^{42}$, irmão da Duqueza morta de Lerma, que mora perto da praça, e ahí lhe deu de merendar. Tornou às nove para a Rainha, donde se foram ambos em hum coche de tela por fora e por dentro, e cortinas de damasco de ouro de nova invenção, e os cocheiros e guarnições de tela branca índia com guarnição de prata, e as damas com seus coches, com infinito número de tochas levadas por todos os pages das senhoras, que deram libré a que elas os pedem. Vieram-se após elas os mais dos fidalgos mancebos e os mais acompanhando os reis, e houve muitas luminárias por onde passaram, com as quais se deu fim à festa deste dia.

\section{8 de Junho}

Dia de S. Pedro nos mandou dizer a malcazada e aquelas senhoras da Plateria que, se quizéssemos hir à tarde à horta do Marquês de Camaraca $^{43}$, as acharíamos lá, e pela menhã em S. Martinho.

Hindo por lá, topamos no caminho humas embuçadas, por onde os deixei e me vim. E deixando as festas de S. Pedro e as que houve em S. Martinho e o que tivemos sobre o assentar da jornada, direi somente como, à tarde, fomos eu e Jorge Castrioto e achamos à porta hum rótulo que dizia: aquí llegaron Phelipe de Morales y Santinbanes, y batieron y no les abrieron.

Batemos e abriram-nos e nos deram muito bem de merendar, mas achamos a horta muito chea e ocupada de penitentes que estavam merendando, e nos ajuntamos: cantaram e dançaram muito bem.

42. Sancho de la Cerda, Marqués de la Laguna, Mayordomo Mayor de la Reina y cuñado del Duque de Lerma una vez que su hermana Catalina de la Cerda casó con el mismo. A la muerte de Juan de Borja en 1606, le sustituyó en el Consejo de Portugal.

43. Francisco de los Cobos y Luna, Marqués de Camarasa y capitán de la guarda española. 
Chegou-se-me a Celestina velha e me disse:

- Pésame mucho que no pueda V. M. hablar a su gusto a Mariquita, que también ella lo dezea, por dezirle ciertas cozas, y holgara que huviera aquí un laberinto donde nos fuéramos. Más días hay que longanizas.

Querendo-lhe responder, não houve lugar. Querendo-nos vir, se adiantaram as outras como gente experimentada fazendo-nos o jogo magro a mim e a D. Maria, que ficávamos na retaguarda, dizendo-nos que fóssemos encomendar à horteloa natilhas para o outro dia, que as vende muito boas. Contudo, as fomos seguindo e, por dissimular, disse D. Maria a D. Joana, que hia falando com Jorge Castrioto:

- Buena está la vellaquería, que se vengan solos dando mal exemplo, y dexen los amigos olvidados tras del leche.

Respondeo D. Joana:

- Y aun por esso, hermana, no quiziste tú comer quezo, porque no coajasse.

Vindo já noite pelo Prado, recolhendo-nos, se envolveo hum corno na roda e, ao voltar, topava no encerado e não o deixava andar; dizendo ao cocheiro como parava, respondeo:

- Um diabo de un cuerno, que no dexa correr el coche.

Acudio D. Maria:

- Pues moneda es ésa que corre,

Detendo-se muito em o tirar, disse eu que o tomava em bom agoiro, pois pegara o corno tão fortemente na roda. Respondeo:

- Y con razón, pues puede V. M. creer que ha <h>echado un clavo a la Rueda de la Fortuna.

E disse D. Joana:

- Buena tierra y buen labrador, que en una tarde sembra [sic] y coge.

Acodio a outra:

- Y aun por esso me guardaré yo de alquilarlas a estrangeros, que, como no quieren propriedad, aprovéchanse del alquiler mientras dura el tiempo.

Deixamo-las hir no coche e ficamos nós no prado, que estava fermosíssimo, ocupado pelo rio de coches, e pela ribeira de infinidade de 
mulheres, humas assentadas, outras bailando; e voltando perto das onze, ao pé de hum álamo estava com huma velha huma moça que me pareceo me dava o ar dela. Ficava atrás Jorge Castrioto:

...e nel viso la guata;

e la conosce subito ch'arriva ${ }^{44}$,

porque, por hum faldelim novo que levou aquele dia, mui apassamanado de ouro, a conheceo por mais que ela abaixava o rostro, que era a mesma que acabávamos de deixar, e por honestidade tinha diante hum mancebo de idade de vinte e dois anos falando com ela; ele, cuidando que me daria pena, fes que a não conhecia. Eu, confirmando a suspeita, embuçando-me, tornei a voltar, onde passou o diálogo seguinte entre a dama e o roque de verbo ad verbum.

D.: Ah, señor galán, no passe V. M. sin hazer cazo de los suyos, que, pues le conoscí a la ida, mal le podré desconoscer a la venida.

R.: Muchos días hay que tengo conoscidas a VV. MM. y ni aora dexé de conoscerlas, mas entendí que con tan buena compañía me havían perdido de vista, pues no me llamavan.

D.: Conténtese V. M. con que es de los escogidos, aunque no sea de los llamados, y dígame cómo me conosció, que yo estava buscando alfileres cuando V. M. passó.

R.: El faldelim fue el parlero y quiera Dios sea ésta la postrera maldición y mancha que caiga sobre él.

D.: Pues por vida de mi marido que el primero que se le ha puesto es V. M. con essas malas palabras y peyores pensamientos.

R.: Verdad es que no me lo merece, pues cuando V. M. tiene escogidos no fui yo de los llamados.

D.: ¿En qué ley cabe, señor regalón, que quiera V. M. que le llamen y busquen las mugeres?; y conténtese con que quien se esconde aún muestra tener vergüença.

Nisto disse o mancebo:

-Señores, yo no quiero meter la mano entre dos piedras y dejo a VV. MM. mejoradas de compañía. Quédense a Dios, que me voy buscar su marido, y iremos también buscar nuestras aventuras.

Elas lhe pediram que o fizesse vir, que era tarde.

Contaram-me que o marido as trouxera, em que lhe pes; e porque não julgássemos mal, abaixara o rostro, e que esperasse até que viesse e me fizesse parente de D. Joana, pois me vira em caza. Disse-lhe eu:

44. Orlando Furioso: C. I, oct. 15: e nel viso la guata; e la conosce subito ch'arriva. Trad. de José María Micó, pp. 8-9: y al ver su rostro cercal la conoce al momento. 
-Doy al diablo tus enredos, que ya te creo, y no espero sino cuando me hagas creer que soy tinaja.

Estando já connosco Jorge Castrioto, passavam três clérigos e ela estava olhando se vinha o marido, dezassocegada. Parou hum e disse:

- Juro a Dios que no deve estar contenta con dos y anda buscando otro.

E ela respondeo:

- Antes, como los quiero tanto, miro si viene el lobo, no me lleve mis corderillos.

Respondi eu:

- En verdad que temo que corderos tan regalados presto vengan a ser carneros. En esto el lobo en la conseja, porque veio penitente.

E ela adiantou-se e disse:

- Tardárase más un poco, señor Sebastián, que ya tenía engañados estos caballeros para que nos fuéramos por esse mundo.

E ele:

- En verdad que ivan ellos bien aprovechados con tal joya, y estoy para bolverme por no atajar la merced que Dios me hazía.

Enfim, depois de muitos comprimentos sobre o novo parentesco, vim eu a dizer mal das mulheres, e em terceira pessoa lhe contei a história toda, e que, andando todo o dia com huma dama, fora tão despejada que, por não perder a noite, a achara com outro. Contei a história do corno e conclui:

\footnotetext{
- De suerte, señor, que pensé que el cuerno venía para el marido y vino para mí.
}

Acodio ela:

- No sea V. M. maliciozo, que ya puede ser que veniesse para entrambos.

Estando neste passo me vieram chamar que fosse ver a mais notável farça e figura que podia haver. Foi o cazo que, passando hum D. Quixote vestido de verde, mui desmazelado e alto do corpo, vio humas mulheres ao pé de hum alto álamo e se pôs de joelhos a enamorá-las. Foi sua disgraça que repararam dous velhacos na postura e convocaram outros e foram acodindo, de sorte que se ajuntaram mais de duzentas pessoas a dizer chistes e a apupar, e ele calava como Sancho, e continuava com sua devoção e encubrindo o rostro como 
assoutado. Dous se foram também pôr de joelhos, dizendo: "No se diga la missa sin acólitos", e começaram a pedir mizericórdia para aqueles penitentes; e a grita e rizo era de sorte que não havia ouvir-se, dizendo ora huns ora outros:

- ¿Han visto, señores, más lindo modo de enamorar?

- Juro a Dios que parese portugués y puede poner escuela de continencias.

- Buelva, señor sacristán, que ya es tiempo de "orate, fratres".

- Señoras, dejen dezarmar esse ballestero, que hay dos oras que está armado.

- Señor grulla, si le cansa essa pierna assiente la otra.

- Échate, perdiguero, que ya hiziste la muestra.

- Dichoza penitencia, que nos cauza tanta gloria.

L'orecchie abbassa, come vinto e stanco destrier c'ha in bocca il fren, gli sproni al fianco. ${ }^{45}$

Agastaram-se as senhoras, dizendo huma que lo harían como villanos, y no como caballeros, pues de estar ellas descubiertas podían pensar que eran mugeres y que no se devía hazer aquel agrabio. Acodio hum:

- !Mientras este pecador está en su penitencia, déjenos rezar y callen ellas y los manden levantar, y se $<h>e c h e, y$ entretanto que él es necio seyan ellas cuerdas, y chitón, que ijuro a Dios que hay aquí otro caballero, sino yo!, porque los demás son príncepes que merecen ser servidos de rodillas, como ellas.

Durou a festa até que veio hum alguazil que da parte do Corregedor lhes pedio que se fossem folgar a outra parte e que era mal feito perderem o respeito aquelas senhoras, pois estavam com os rostros descubertos, que aquele fidalgo era marido de huma, por isso estavam assim por zombar e rir. Mas era mentira. Com esta fábula se acabou a farça e nos viemos a tempo que se hiam as conhecidas; e a velha, deixando-se ficar, me disse:

- Quando V. M. quiziere hablar a esta niña, embiémelo a dezir, que, como no haya coza dezonesta, como de V. M. veo, me holgaré darle a ella esse gusto porque tiene muchas pezadumbres y pocos desenfados con este mal hombre.

E o pecador não tinha onsa de mal.

E as mais e sogras são as que ordinariamente deitam a perder as filhas e noras, que, como as levam em sua companhia, logo andam em merendas e em coches; e pelos mimos que herdam trazem as filhas e noras a estas romarias, e por si se vêm os sucessos que às vezes no princípio não cuidaram; e elas à sombra das mais andam seguras, além da sua boa habilidade com que zombam dos pobres maridos. E notamos que ordinariamente os maridos destas andam,

45. Orlando Furioso: C. XX, oct. 131: L'orecchie abbassa, come vinto e stancol destrier c'ha in bocca il fren, gli sproni al fianco. Trad. de José María Micó, pp. 830-831: con las orejas gachas, cual caballo/ al que el freno y la espuela ya han domado. 
como gente pasmada, abobados: ou que elas os escolham assim ou que lhes dêem algumas confeições para os trazerem à sua mão.

Lembra-me que a outra ves que cá estive me pedio hum amigo que fosse com ele despedir-se de huma sua conhecida, porque se vinha para Portugal. Subimos à caza de huma vezinha que morava no derradeiro sobrado. A madona era cazada com hum alguazil que estava enfermo. Subiu-se ela assima e esteve em boa prática -que a tinha ela muito boa e melhor rostro-, achandoa menos o marido, e que estava em sima, tendo-lhe ele prohibido, chamou huma mulata que tinha, dizendo-lhe que lhe abrisse a porta. Falou a mulata alto por que a ouvissem onde queria hir.

- ¡Baja, vellaca, y tráeme las medias y los sapatos y dame acá la espada, que la he de matar, pues va sin mi licencia!;

porque parece que sem meias e sapatos não se podia fazer o sacrifício.

Enfim, baixou ela mui dessimulada com a almofada e nós até o pé da escada. Abrio-lhe a mulata e eu, como não vi pólvora para muito, pus-me a espreitar e ouvi que lhe disse estas formais palavras:

- ¿Dónde vienes, vellaca? ¿No te mandé que no subieces arriba? ¿De qué te turbas, Isabel? Mira aquella boca desvergonçada y essos labios tan descoloridos y bezados, como se trataras con algún lobo.

Ela, fingindo indignação, disse:

- Desvergonçado, infame, que boca y pecho onde han cabido tales palabras bien merecía que se las hiziesse verdaderas; si tú fueras hombre, quitárasme la vida, pues tal pensavas, y no hablaras tales palabras de tu muger, mas eres infame; por vida de mi madre que no he [de] dormir en esta caza. Váyanme lá llamar, y báxame mi cama abajo, que no he de quedar en esta caza.

E com isto se baixou, rindo; e abraçando o outro, lhe disse:

- Vaya, hermano, con Dios, y no se enoje, que ya esto queda templado, y ansí fuera la buelta presto, como él me vendrá a rogar presto.

Tanta habilidade têm estas para os seus enredos. E assim com rezão dizia André de Macedo que à sombra da crus que o marido fas quando se benze:

Ma chi del Canto mio piglia diletto,

un'altra volta ad ascoltarlo aspetto. ${ }^{46}$

46. Orlando Furioso: C. XVIII, oct. 192: Ma chi del Canto mio piglia diletto, / un altra volta ad ascoltarlo aspetto. Trad. de José María Micó, pp. 732-733: Espero que el que goce con mi canto/vuelva en otra ocasión para escucharlo. 


\section{TRADUCCIÓN AL CASTELLANO}

10 de junio. Fiesta de cañas y toros en honor del nacimiento del príncipe.

Expectata dies aderat, porque el 10 de junio, viernes, se hizo la principal fiesta de cañas y toros, para la que los ingleses andaban muy alborozados por ser fiestas que allí no usan.

Se concentraron por la mañana dieciséis toros con muchos caballeros, que los van a esperar a una legua y vienen haciendo suerte, que es una media fiesta.

Se cubrió toda la plaza de arena fina, de cuatro dedos de alto, de manera que quedó como la palma de la mano, principalmente después de regada y empapada en agua, lo que hacen muy rápidamente y con muy buena invención, porque ponen dieciséis carros en fila, con sus vasijas y en los tornos dos mangueras de cuero y, meneándolas, van regando y los carros van corriendo, de forma que en menos de tres credos queda regada y fresca la plaza; y esto lo hacen muchas veces.

La plaza es la más hermosa que tiene Valladolid, como ya he dicho, toda de columnas alrededor, muy gruesas, de 185 pasos de largo y de una sola pieza, con sus capiteles encima, y tiene saledizos debajo, y por encima una balconada de veintinueve arcos en la fachada, lo que la convierte en una hermosísima casa.

Armaron ahora el palenque desde la primera ventana hasta el suelo, de modo que quedó la plaza más sorprendente y más hermosa, y los palenques segurísimos, y cabrían en ellos entre diez y doce mil personas.

Tiene la plaza tres filas de ventanas en los tres pisos, y en cada fila hay cien ventanas, y sobre ellas terrazas con su barandilla, que toman toda la anchura de la primera casa, y detrás de ella diez con muchas ventanas sobre la terraza, que hacen doscientas ventanitas. Y como todas están en una posición y correspondencia y toda la fachada de la misma labor del ladrillo queda hermosísima, y se hizo toda por una traza, porque se quemó la cuarta parte de la ciudad y cuando se reedificó en tiempos del rey viejo se ordenó y trazó toda de una manera, guardando la misma simetría en toda la plaza y más calles que se hicieron.

Estaban todos estos lugares ocupados y de los tejados se quitaron las tejas, y estaba la gente apiñada sobre ellos. Entran en la plaza veinticuatro calles y en ellas se hicieron tablados de dos pisos que las ocupaban. Hicimos cálculo de la gente que podía haber sentada y hallamos que serían más de cuarenta mil personas, y, con haber tantos asientos, nos costó un lugar para ambos doscientos reales, aunque valían mil y ochocientos los ordinarios; y así, cuando los dueños alquilan estas casas reservan para sí estos días, que les rentan más que todo el alquiler del año. Y aunque las dan a los alcaldes de corte, se paga la mitad.

A las once estaban ya todos los lugares ocupados de la siguiente forma: casi todas las ventanas fueron ocupadas por los consejeros; dieron los arcos de 
arriba y los de debajo del consistorio a los ingleses principales, y a los demás dieron los palcos, que escogieron en los palenques de las calles señoritos que los hicieron; y casi todas las ventanas se dejan a mujeres, que ninguna pierde ocasión de holgar en estas coyunturas, todas riquísimamente vestidas. Las ventanas muy adornadas en el corto y pequeño sitio que hay entre unas y otras.

Cuando el rey ve las fiestas tiene su dosel y ninguna otra persona lo puede tener, ni quitasol, ni cosa alguna de seda para arriba, y así hicieron por encima unos toldillos de estopa sobre ellas para el sol y con lonas los tejados.

A las once vinieron los trompetas, atabales y chirimías de la ciudad, que fueron veinticuatro, con telilla de tela falsa sobre tafetán encarnado, sombreros y banderas y mangas de los atabales de lo mismo, que se repartieron en las cuatro esquinas de la plaza, donde tenían sus palenques.

Cerca de las doce entraron los reyes que habían de comer en el consistorio con mucho aparato, y fue de esta manera: entraron inmediatamente algunos carros y carrozas de mujeres de los grandes y señoras que habían de estar con la reina, porque ella y sus damas venían en jacas. Se seguían veinte pajes del rey a pie; tras ellos los titulares y señores de la corte, que eran ochenta, y veinticinco que venían detrás con las damas, vestidos admirablemente de brocado y con toda la riqueza que se puede imaginar, cargados de oro, perlas y piedras en las cadenas, botones y cintillos, que para este día reservaron lo mejor, y como hacía gran calor y sol, cegaban a la gente los rayos que salían de las piedras y medallas, que todo lo bueno de España iba en ellos y en las damas.

Y en esta universal holganza, para no faltar entremés, apareció un D. Quijote que iba delante como aventurero, solo y sin compañía, con un sombrero grande en la cabeza y una capa de bayeta y mangas de lo mismo, unos calzones de velludo y unas buenas botas con espuelas de pico de pardal, batiendo las ijadas a un pobre cuartago rucio con una rozadura en el borde del lomo, de las guarniciones del carro, y una silla de cochero; y Sancho Panza, su escudero, delante. Llevaba unos anteojos para dar más autoridad y bien puestos, y la barba alzada, y en mitad del pecho un Hábito de Cristo; y como iba solo y en aquella figura comenzaron a preguntarnos unas vecinas si era el Embajador de Portugal o qué cosa era aquélla. Se mi dimanda alcun chi costui sia diré que era el Sr. Jorge de Lima Barreto, que por honor de Portugal reprehendió de malos cortesanos a la mayoría de los señores portugueses y quiso acompañar a su rey con esta librea, y tomó un caballo de su carro que no quería dar paso:

di cento punte l'asinello offese,

né di sua tardità però lo tolle.

Y por estas y otras tales somos oprobio de las gentes y desprecio de los castellanos. Volviendo a la historia, tras los hidalgos iban los mozos de la reina a caballo; se seguían todos los grandes que están en la corte, que son los que he contado, y los principales con los vestidos que después diré; después los escuderos de la cámara y lacayos del rey y de la reina delante de ella y del rey. 
Venía la reina en una hacanea blanca hermosísima, en un sillón de plata dorada y esmaltado, con algunas piedras engastadas, con gualdrapa de velludo negro, todo bordado de lacarcias de oro y plata y canutillo de oro y guarniciones de lo mismo, y ella con falda ancha o cota de cabalgar, de tela de oro roja, con bordadura de aljófar. A su lado el rey, con la misma librea y colores que la reina: capa, gorra y batín negro, pantalones rojos, forros blancos y plumas de las mismas colores; detrás de la reina, la camarera mayor y otras dos damas en literas con gualdrapas de luto. Luego quince damas de la reina sobre muy hermosos palafrenes con sillones de plata, gualdrapas de velludo, con pasamanos de oro o bordado de canutillo y rosas; por el medio, de oro y plata -que nunca Oriana en su tiempo con más grandeza probó el Arco de los Leales Amadores, aunque llevaba consigo a la señora D. Brides y a la señora Dulcinea del Toboso-, y todo era necesario para pasar las caras falsas de las damas, que parece que escogieron una y una, si no es tal y tal. Venían vestidas con mucha riqueza, de diferentes colores, pero todas de cotas anchas golpeadas con sus moscas de oro y plata menudas, y las más bordadas en lugar de las guarniciones. Iban dos meninas de la infanta más, una de ellas muy hermosa; las llevaban embridadas lacayos de la reina, y con cada uno iban uno o dos galanes como Ángeles de la Guarda.

Llegando al consistorio bajó a la reina su mayordomo mayor; a las damas, sus hermanos o parientes que las acompañaban, o los hidalgos viejos, mayordomos y guardadamas y otros, como es costumbre. Al rey le tomó el estribo el Duque de Lerma como estribero mayor. Fue esta entrada de las cosas que más holgué de ver por lo desusado de ver entrar a las damas a caballo y con tanto concierto y majestad. Y así, de estas fiestas los accesorios fueron lo más principal, como torneo que no tiene que ver más que las entradas.

Los que más galanes salieron durante estos días fueron los príncipes, que, a causa del luto que traían por la muerte del hermano y fiesta del príncipe, salieron de negro y plata, a saber, bordado de tela de plata y canutillo de ella sobre velludo negro, las labores muy descubiertas y realzadas, a la manera de los guadamecíes negros dorados, pero las rosas pequeñas, capas, pantalones, batines, gualdrapas y guarniciones, todo de una suerte, que sobresalía y brillaba mucho más que todas las cosas.

El segundo, el Duque de Alba, con otro vestido y gualdrapa, bordado de oro sobre azul, tan costoso y rico como los primeros.

El tercero, D. Juan de Tassis, con un tercer vestido y gualdrapa de bordado menudo de tela de plata o telilla que brillaba mucho, donde se descubría a través del follaje de oro que la cubría, con unas rosas o flores levantadas con mucha argentería, y principalmente en el tocado y cuera y bordado, entrecruzadas piezas y botones de diamantes en la obra del bordado.

El cuarto, el Marqués del Valle, de camelote de oro azul con doce pasamanos u orlas de tela alineada, pantalones de canutillo, gualdrapas azules, con tantos pasamanos de oro que casi la cubrían, y los forros de tela.

El quinto, el hijo de Franqueza, a la jineta, porque tiene los mejores treinta y dos caballos que hay en la corte, y el aderezo de aljófar y piedras o per- 
las, riquísimo, y él de camelote de oro rojo, con doce orlas sobrehiladas de brocado, chaleco y pantalones de canutillo y con infinidad de joyas y diamantes.

Comieron los reyes en el consistorio en público y las damas nos sirvieron la cena.

A la una entró el Presidente del Consejo Real, el Conde de Miranda, con esta majestad: llevaba delante veintisiete alguaciles muy bien trajeados, y en muy hermosos jinetes cuatro Alcaldes de la Corte, el Corregidor de Valladolid, quince Oidores del Consejo Real; llevaba siempre detrás de sí, por derecho, carro, litera y silla. Éste es muy soberbio y vanidoso, así de espíritu como de cuerpo, consuegro del Duque de Lerma, y este oficio es la segunda persona después del rey.

A las dos entró la guarda de los alabarderos en hileras, que pareció muy bien, y comenzaron a vaciar de gente la plaza, haciéndola salir, en lo que hubo mucho trabajo. Quedando despejada, la regaron con los carros y quedó hermosísima, ocupándose todas las ventanas, de suerte que en cada una había dieciséis o veinte personas.

A las tres salió el rey e inmediatamente la reina, la cual fue a buscar al Almirante Embajador, que ya estaba ahí.

Tiene el consistorio diecinueve arcos: en el del medio permanecen los reyes, y el rey dijo al duque: sede a dextris meis; y así estaba cubierto en el mismo arco y balcón, echando a los alguaciles de allí, y ninguna otra persona, porque los más grandes quedaron detrás de las sillas; en los dos arcos de la mano derecha los príncipes con sus criados detrás, y en los otros los ingleses principales. Las damas tenían los nueve arcos de la mano izquierda, y, por más honor, se hizo sitio entre ellas al Almirante, que supo escoger el mejor, que es la infanta D. Catalina de Lacerda, a quien dio una joya de mucho precio.

Estando la plaza en este estado y los asientos ocupados así, con mucho alborozo y estruendo de los instrumentos que estaban en sus palenques entraron algunos toreros: el primero D. Vicente Zapata, con ocho lacayos de pantalones y jubones de leonado y guarnición amarilla, cuera blanca, todo acuchillado y forrado de telilla de plata que se descubre por los golpes, y estas cueras blancas sacan todos los lacayos.

Luego ocho con título, que fueron el Duque de Alba, el Marqués de Cerralbo, el de Barcarrota, el de Coruña, el de Ayala, D. Antonio de Toledo, el de Távara, el Conde de Salinas. Después fueron entrando otros hidalgos y señores con diversas libreas. Los primeros, veinticuatro lacayos de morado y rojo golpeado, con sus entre forros de velillo o telillas, cueras blancas; otros doce lacayos de negro y blanco con pasamanos de plata; otros seis de negro, mangas y forros blancos; otros seis de rojo y morado; otros tres de leonado y blanco; otros ocho de leonado y amarillo; otros seis se rojo y blanco, todos de tafetán, sombreros cuarteados de las mismas con plumas y los pasamanos de oro y plata falsa, y los forros de velillos de plata, de colores, y todos con sus rejones. Estos vestidos no sirven más que este día y, si al otro hay otros toros, han de sacar otros y no los mismos, y así se venden inmediatamente gratis. 
Quien mejor lo hizo fue el Marqués de Barcarrota, que rompió algunos rejones intrépidamente. También lo hizo bien D. Pedro de Barros, que metió un garrochazo a un toro por la cerviz, de suerte que le pasó la garganta y se vació en sangre por la boca y cayó rápidamente a pocos pasos.

Queriendo acudir, al entrar, al Duque de Alba el toro mató un caballo, que se le salieron las tripas y le había costado mil cruzados pocos días antes.

Mataron otros dos caballos sin suceder cosa notable, porque inmediatamente matan los toros o bien con garrochas o bien a cuchilladas los mismos de a caballo, que, como locos, los rodean y despedazan a los pobres bueyes con cortes por los rostros y ancas, que todos los llevan muertos los ganapanes y algunos quedan para los perros.

Vinieron también a lancear al toro dos hidalgos de fuera, poco conocidos por el nombre y menos por las obras, uno de ellos llamado Martín Leal, que no lo fue en esperar al toro con los ojos del caballo tapados, y pasando el cuitado, le metió a traición la lanza por las ijadas, y corriendo el toro se la quitó de la mano sana y salva, levantada en el aire como garrocha, y murió de ahí a poco. Volvió a esperar otro y, como era negro, no acertó en el blanco y no hizo nada. El compañero lo hizo menos mal, que le esperó cara a cara y, aunque dio la lanzada delante de la cruz, se desvió mucho, rompiendo la lanza, y el toro murió de ahí a poco.

Ya en otra ocasión vi dar estas lanzadas a toros a D. Jerónimo de Aiansa y dar grandes impulsos con una lanza con una antena, y no hizo nada; y poco más otro hidalgo que salió entonces, y es temeridad estúpida.

Mejor anduvo D. Gonzalo Chacón desde la otra vez que aquí estuve, que diciendo el rey durante la cena que había holgado de ver correr unos toros, al día siguiente se andaban corriendo en frente del palacio, a las tres, con muy hermosos palenques. Y esperando D. Gonzalo Chacón un toro con una lanza, le acertó por la cruz y lo atravesó de suerte que volvió con la barriga hacia arriba delante del caballo.

Y el día diez de éste, en Medina del Campo, me contaron que, esperando un pecador al toro, se le espantó el caballo oyéndolo venir, y dio con él de espaldas en la arena; y volviendo a venir en el mismo caballo miedoso, dio al toro en la cabeza, y empinándosele el caballo volvió a dar con las costillas en la arena, y está el pecador muriéndose de disgusto.

Volviendo a nuestros toros, a las seis se habían corrido doce o trece, y porque comenzaba la sombra, se fueron el rey y el duque a vestir sus libreas para las cañas, que fue una de las más soberbias fiestas que dicen se hizo en España.

Al salir el rey, se despejó la plaza haciendo sentar en el suelo a algunas personas que permanecieron. Luego entraron veinticuatro carros enramados con banderas de los colores de la ciudad, que parecían grandes árboles; y saliendo en fila, regaron la plaza acudiendo la gente a tomarla con sombreros en las cabezas, que se estaban abrasando; y fue otra nueva fiesta, que parecía la plaza montaña, volviéndose a despejar.

Entraron en la plaza doce atabaleros, ellos y las cubiertas de los caballos de tafetán encarnado y forros morados a dos barras, de pasamanos de plata, 
ellos de ropas rozagantes de estos dos colores; sombreros, mangas de los atabales y todo lo demás de debajo, de velillo de plata.

Luego veinticuatro trompetas, todas a la jineta, con guarniciones, capuchones y jirones de los caballos y banderas de las trompetas todas de la misma suerte, y todos venían en jacas del rey, muy hermosas y de mucho precio y bien equipadas.

A continuación, seguían doce acémilas del rey con cañas por encima, reposteros de velludo carmesí bordados a la redonda, de oro y plata, de despojos y trofeos, y en medio las armas reales ordinarias, de broslado, con sus colores y con la corona imperial. Las alabardas, cuerdas, sobrecargas, cabestros y sillas, todo de seda y retrós, y lo mismo en los pectorales, con franjas hasta las rodillas de carmesí y blanco; los cordones de las colas de las cintas de Colonia en mazos, paquetes y planchas de las testeras, de plata maciza, con las armas reales; plumas grandísimas en las cabezas y ancas, del mismo color. Llevaban los acemileros los mismos colores y trajes de las trompetas, excepto que eran de velludo carmesí, con pasamanos y morenillos de plata fina. Tras ellos dieciséis oficiales de caballerizas, como furrieles, guarda-arneses, maestros de los pajes y otros, todos descubiertos y vestidos de negro, con sus cadenas de oro. Luego los pajes del rey a pie, con sus libreas ordinarias de negro.

Entraron luego veintiséis caballos del rey con sus aderezos y jaeces de jineta, cuales se puede imaginar, y por encima sus tellices, que son cubiertas grandes, como gualdrapas sobre las sillas, que lo ocupan todo hasta el suelo, del mismo cabello carmesí con su bordadura alrededor de oro; y en medio, en lugar de armas, una cifra del nombre de Phelipus tertius, de oro, y ramos de lacería que lo ocupaban todo, y encima corona de plata acabada, de modo que quedaban lustrosísimos. Los llevaban veintiséis lacayos de pantalones y ropillas de nácar, con randas de oro, todo golpeado sobre telilla de plata, cendales azules con puntas de oro, zapatos de velludo blanco, forros del mismo color además de la telilla.

Acto seguido iban los caballos de los príncipes a la derecha. Venían delante cuatro lacayos de negro y plata, forros y mangas de telilla con dos adargas con barras plateadas en campo negro; luego sus doce pajes a pie, de su misma librea.

Entraron luego cuatro caballos del príncipe menor con los tellices de velludo negro con puntas redondas u ondeadas por debajo, todos bordados de canutillo de plata riquísimamente. Los otros ocho, para llegar al número doce, no se pudieron acabar a tiempo que pudiesen entrar. Tras ellos venían doce caballos del príncipe Víctor Amadeo, del mismo velludo negro y la orla de plata de canutillo y escarchada, y el cuerpo de los tellices sembrado de estrellas de plata, de modo que parecían mejor que todos aun siendo del mismo costo; los llevaban ocho lacayos de la misma librea que los cuatro primeros.

Entraron seis caballos más enjaezados con adargas blancas y barras de oro que llevaban lacayos del rey, y por ser tarde no entraron los demás.

Después venían veintiún caballos enjaezados que llevaban otros tantos lacayos de verde y plata, jubones blancos de telilla y morenillos de plata, pantalones todos apasamanados de plata, medias verdes, zapatos blancos, plumas 
y sombreros del mismo color, y eran del condestable y su cuadrilla, que ésta fue su librea.

Había otros cuantos caballos más, que era un número infinito el que estaba para entrar de las otras cuadrillas, y con estar los lacayos todos de librea y ellos con jaeces de aljófar y otras invenciones, no pudieron entrar porque faltaba día para ello, e hicieron salir los que iban entrando por la parte izquierda, donde estaba la reina, y volvieron por la otra.

Es cierto que contemplar la plaza de esta manera era el más hermoso espectáculo que se puede imaginar, y fue una lástima que comenzasen tan tarde por temor del calor.

Entraron luego las cuadrillas, que eran ocho, corriendo en parejas de dos, cada cuadrilla sobre sí con sus colores diferentes, como diré después. En cada cuadrilla había diez y hacían un total de ochenta, y eran cuadrilleros los siguientes:

$\begin{array}{ll}\text { El rey y su librea, de nácar } & 1 \\ \text { El Duque del Infantado, rojo y blanco } & 2 \\ \text { El Duque de Alba, rojo y azul } & 3 \\ \text { El de Pestana, azul y blanco } & 4 \\ \text { El Conde de Alba de Liste, amarillo y azul } & 5 \\ \text { La ciudad, de blanco y negro } & 6 \\ \text { El Condestable } & 7 \\ \text { Los príncipes, de negro y blanco } & 8\end{array}$

Eran las libreas de satén bordado y forro de telilla en las marlotas o vaqueros, con mantos o capas a modo de mantillas a la romana, tomados en el hombro izquierdo, del mismo satén bordado de tela falsa en ramos, troncos y diversos follajes y labores, tomadas con torzales de plata y oro, con canutos de plata batida en relieve, y otros modos e invenciones en cada cuadrilla.

Las ordinarias eran falsas, pero algunos señores las mandaron hacer de tela y plata fina, que valían mucho dinero. Los tocados, de diversas invenciones, a la turquesca y morisca, todos con pedazos de plata, oro y aljófar y otras piezas turcas, enmarañadas sobre barretas de colores con trenzas bordadas y picos como de diamantes, puntas y botones y medallas de oro y pedrería, y por encima turbantes grandes con sus martinetes y otras plumas; los caballos con cubiertas, borlas y jirones de la misma obra, pantalones y mangas al antojo de cada uno.

Entró el rey corriendo con el duque en dos caballos blancos, con mucha gracia y donaire; luego los otros ocho de su camarada, que fueron el Duque de Cea, el Conde de Lemos, el Marqués de S. Germán, el Conde de Gelves, el de Mayalde, D. Pedro de Castro, D. García de Figueroa, D. Martín de Aragón; luego el Condestable con los de su cuadrilla; y la última la de los príncipes, y ellos detrás de todos, que pareció muy bien porque los hacían brillar los buenos caballos en que venían y la hermosura de los colores que iban descubriendo. El rey y el duque lo hicieron mejor y con más donaire que todos, y los príncipes, así como fueron últimos, merecieron este mismo lugar. Fueron 
después corriendo por la parte de la reina, la tercera carrera por la otra parte y la cuarta por el medio hacia la puerta por donde entraron, después de esquina a esquina en cruz y quedaron repartidos en dos partes, guiando el rey una y el condestable otra. Fueron tejiendo una tela en hilera, atravesando una hilera junto a otra y haciendo su medio caracol sin equivocarse, que pareció muy bien, y se fueron a tomar otros caballos, y quedó la plaza pequeña para ellos, aun teniendo 185 pasos, que son varas de cinco palmos.

Volvieron a entrar repartidos en cuatro cuadrillas, introduciéndose dos en cada una, que tomaron las adargas solo de cuatro divisas. No corren las cañas como nosotros, sino que van saliendo en tropel los de una esquina y acometen a los de aquella parte y luego vuelven a por los de la otra esquina, y ésos en tropel los van siguiendo hasta su lugar y vuelven a por los de la otra parte que los siguen, diez huyendo y diez siguiendo, y así continúan las cañas.

Entre todos anduvo más airoso el rey, seguro en la silla y con tanto donaire en la caña y adarga que naturales y extranjeros, sin excepción alguna, le dieron el primer lugar, y a mí me pareció lo mismo, y a todos nos alegró mucho, porque el rey a pie no muestra tanto, y a caballo o bailando parece en extremo bueno; y lo mismo querrá Dios que sea en las cosas verdaderamente, lo que yo no sé, porque no las vi.

Se cerró en esto la noche, faltando el día y no [la] fiesta, que los caballos del Sol, envidiosos de los jinetes de España, es normal que se apresurasen a ello.

Fue la entrada, así por el aparato como por el lugar y conjunción en que se hizo, una de las grandiosas fiestas que se hicieron en España, porque en aquella plaza, debido a la igualdad y hermosura de ella, estando tan fresca y bien ornada, brilla mucho más; y juntamente por ver todos el gusto que tienen los naturales de que los extranjeros vean aquello en que se aventajan a las otras naciones, hace recibir más contentamiento de estas grandezas y parecer todo mucho más maravilloso; y sin duda se asombraron los ingleses mucho de ellas.

Se fue el rey a vestir camisa a casa del Marqués de Laguna, hermano de la Duquesa muerta de Lerma, que vive cerca de la plaza, y allí le dio de merendar. Volvió a las nueve hacia donde estaba la reina, de donde se fueron ambos en un coche de tela por fuera y por dentro, y cortinas de damasco de oro de nueva invención, y los cocheros y guarniciones de tela blanca india con guarnición de plata, y las damas con sus coches, con infinito número de teas llevadas por todos los pajes de las señoras, que dieron librea a quienes se la pidieron. Se vinieron tras ellas la mayoría de los hidalgos mancebos y la mayoría acompañando a los reyes, y hubo muchas luminarias por donde pasaron, con las cuales se dio fin a la fiesta de este día.

\section{8 de junio}

El día de S. Pedro nos mandó decir la malcasada y aquellas señoras de la Platería que, si queríamos ir por la tarde a la huerta del Marqués de Camarasa, las encontraríamos allí, y por la mañana en S. Martín. 
Yendo hacia allí, nos encontramos en el camino a unas embozadas, por donde los dejé y me vine. Y dejando las fiestas de S. Pedro y las que hubo en S. Martín y lo que tuvimos sobre el asiento de la jornada, diré solamente cómo, por la tarde, fuimos yo y Jorge Castrioto y encontramos en la puerta un rótulo que decía: Aquí llegaron Felipe de Morales y Santinbanes, y batieron y no les abrieron.

Llamamos y nos abrieron y nos dieron muy bien de merendar, pero encontramos la huerta muy llena y ocupada de penitentes que estaban merendando, y nos acercamos; cantaron y bailaron muy bien.

Se me acercó la Celestina vieja y me dijo:

- Pésame mucho que no pueda V. M. hablar a su gusto a Mariquita, que también ella lo desea, por decirle ciertas cosas, y holgara que hubiera aquí un laberinto donde nos fuéramos. Más días hay que longanizas.

Queriéndole responder, no tuve lugar. Queriéndonos venir, se adelantaron las otras como gente experimentada haciéndonos el juego delgado a mí y a D. María, que nos quedábamos en la retaguardia, diciéndonos que fuésemos a encargar a la hortelana natillas para el día siguiente, que las vende muy buenas. Sin embargo, las fuimos siguiendo y, por disimular, dijo D. María a D. Juana, que iba hablando con Jorge Castrioto:

- Buena está la bellaquería, que se vengan solos dando mal ejemplo, y dejen los amigos olvidados tras de la leche.

Respondió D. Juana:

- Y aun por eso, hermana, no quisiste tú comer queso, porque no cuajase.

Viniendo ya la noche por el prado, recogiéndonos, se enganchó un cuerno en la rueda y, al volver, hacía contacto en el encerado y no lo dejaba andar; al decir al cochero por qué paraba, respondió:

- ¡Un diablo de un cuerno, que no deja correr el coche!

Acudió D. María:

- Pues moneda es ésa que corre.

Deteniéndose mucho en sacarlo, dije yo que lo tomaba como buen augurio, pues se había adherido el cuerno tan fuertemente en la rueda. Respondió:

- Y con razón, pues puede V. M. creer que ha echado un clavo a la Rueda de la Fortuna.

Y dijo D. Juana: 
- Buena tierra y buen labrador, que en una tarde siembra y recoge.

Acudió la otra:

- Y aun por eso me guardaré yo de alquilarlas a extranjeros, que, como no quieren propiedad, aprovéchanse del alquiler mientras dura el tiempo.

Las dejamos ir en el coche y nosotros nos quedamos en el prado, que estaba hermosísimo, ocupado por el río de coches, y por la ribera de infinidad de mujeres, unas sentadas, otras bailando; y volviendo cerca de las once, al pie de un álamo estaba con una vieja una moza que me pareció que tenía un aire a ella. Detrás se quedaba Jorge Castrioto:

...e nel viso la guata;

e la conosce subito ch'arriva,

porque por un faldellín nuevo que llevó aquel día, muy apasamanado de oro, la conoció por más que ella abajaba el rostro, que era la misma que acabábamos de dejar, y por honestidad tenía delante un mancebo de edad de veintidós años hablando con ella; él, creyendo que me daría pena, hizo como que no la conocía. Yo, confirmando la sospecha, embozándome, volví de nuevo, donde tuvo lugar el diálogo siguiente entre la dama y el roque de verbo ad verbum.

D.: ¡Ah, señor galán, no pase V. M. sin hacer caso de los suyos, que, pues le conocí a la ida, mal le podré desconocer a la venida!

R.: Muchos días hay que tengo conocidas a VV. MM. y ni ahora dejé de conocerlas, mas entendí que con tan buena compañía me habían perdido de vista, pues no me llamavan.

D.: Conténtese V. M. con que es de los escogidos, aunque no sea de los llamados, y dígame cómo me conoció, que yo estaba buscando alfileres cuando V. M. pasó.

R.: El faldellín fue el parlero y quiera Dios sea ésta la postrera maldición y mancha que caiga sobre él.

D.: Pues por vida de mi marido que el primero que se le ha puesto es V. M. con esas malas palabras y peores pensamientos.

R.: Verdad es que no me lo merece, pues cuando V. M. tiene escogidos no fui yo de los llamados.

D.: ¿En qué ley cabe, señor regalón, que quiera V. M. que le llamen y busquen las mujeres?; y conténtese con que quien se esconde aún muestra tener vergüenza.

En esto dijo el mancebo:

- Señores, yo no quiero meter la mano entre dos piedras y dejo a VV. MM. mejoradas de compañía. Quédense a Dios, que me voy [a] buscar [a] su marido, y iremos también [a] buscar nuestras aventuras. 
Ellas le pidieron que le hiciese venir, que era tarde.

Me contaron que el marido las había traído, de lo que le pesó; y para que no pensásemos mal, había abajado el rostro, y que esperase hasta que viniese y me hiciese pariente de D. Juana, pues me había visto en casa. Le dije yo:

- Doy al diablo tus enredos, que ya te creo, y no espero sino cuando me hagas creer que soy tinaja.

Estando ya con nosotros Jorge Castrioto, pasaban tres clérigos y ella, inquieta, estaba mirando si venía el marido. Se paró uno y dijo:

- Juro a Dios que no debe estar contenta con dos y anda buscando otro.

Y ella respondió:

- Antes, como los quiero tanto, miro si viene el lobo, no me lleve mis corderillos.

Respondí yo:

- En verdad que temo que corderos tan regalados presto vengan a ser carneros. En esto el lobo en la conseja, porque vino penitente.

Y ella se adelantó y dijo:

- Tardárase más un poco, señor Sebastián, que ya tenía engañados estos caballeros para que nos fuéramos por ese mundo.

Y él:

- En verdad que iban ellos bien aprovechados con tal joya, y estoy para volverme por no atajar la merced que Dios me hacía.

En fin, después de muchos cumplidos sobre el nuevo parentesco, terminé yo por decir mal de las mujeres, y en tercera persona le conté toda la historia, y que, estando todo el día con una dama, había sido tan despejada que, por no perder la noche, la había encontrado con otro. Conté la historia del cuerno y concluí:

- De suerte, señor, que pensé que el cuerno venía para el marido y vino para mí.

Acudió ella:

- No sea V. M. malicioso, que ya puede ser que viniese para entrambos.

Estando en este paso me vinieron a llamar que fuese a ver la más notable farsa y figura que podía haber. Fue el caso que, pasando un D. Quijote vestido de verde, muy maltratado y alto de cuerpo, vio a unas mujeres al pie de un 
alto álamo y se puso de rodillas a enamorarlas. Su mala suerte fue que dos bellacos repararon en la postura y convocaron a otros y fueron acudiendo, de suerte que se congregaron más de doscientas personas diciendo chistes y gritando contra él, y él callaba como Sancho, y continuaba con su devoción y encubriendo el rostro como azotado. Dos se fueron también a poner de rodillas diciendo: “¡No se diga la misa sin acólitos!”, y comenzaron a pedir misericordia para aquellos penitentes; y la grita y risas eran de suerte que no había quien se escuchase, diciendo ora unos ora otros:

- ¿Han visto, señores, más lindo modo de enamorar?

- Juro a Dios que parece portugués y puede poner escuela de continencias.

- Vuelva, señor sacristán, que ya es tiempo de orate, fratres.

- Señoras, dejen desarmar ese ballestero, que hay dos horas que está armado.

- Señor grulla, si le cansa esa pierna asiente la otra.

- Échate, perdiguero, que ya hiciste la muestra.

- Dichosa penitencia, que nos causa tanta gloria:

L'orecchie abbassa, come vinto e stanco destrier c'ha in bocca il fren, gli sproni al fianco.

Se enfadaron las señoras, diciendo una que lo harían como villanos, y no como caballeros, pues de estar ellas descubiertas podían pensar que eran mujeres y que no se debía hacer aquel agravio. Acudió uno:

- Mientras este pecador está en su penitencia, déjenos rezar y callen ellas y los manden levantar, y se eche, y entretanto que él es necio sean ellas cuerdas, y chitón, que ijuro a Dios que hay aquí otro caballero, sino yo!, porque los demás son príncipes que merecen ser servidos de rodillas, como ellas.

Duró la fiesta hasta que vino un alguacil que de parte del corregidor, les pidió que se fuesen a holgar a otra parte, y que estaba mal hecho perder el respeto a aquellas señoras, pues estaban con los rostros descubiertos, que aquel hidalgo era marido de una; por eso estaban así, para mofarse y reírse. Pero era mentira; con esta fábula se terminó la farsa y nos vinimos a tiempo que se iban las conocidas; y la vieja, dejándose caer, me dijo:

- Cuando V. M. quisiere hablar a esta niña, enviémelo a decir, que, como no haya cosa deshonesta, como de V. M. veo, me holgaré darle a ella ese gusto porque tiene muchas pesadumbres y pocos desenfados con este mal hombre.

Y el pecador no tenía ni una onza de maldad.

Y las madres y suegras son las que ordinariamente echan a perder a las hijas y nueras, que, como las llevan en su compañía, inmediatamente andan en meriendas y en coches; y, por los mimos que heredan, traen a las hijas y nueras a estas romerías, y por sí mismo llegan los éxitos que a veces, en un principio, no habían imaginado; y ellas a la sombra de las madres andan seguras, 
además de su buena habilidad con la que se mofan de los pobres maridos. Y nos dimos cuenta de que ordinariamente los maridos de éstas andan, como gente pasmada, embobados: o bien porque ellas los escojan así o bien porque les den algunas confecciones para tenerlos comiendo de su mano.

Me acuerdo de que en otra ocasión que aquí estuve me pidió un amigo que fuese con él a despedirse de una conocida suya porque se venía a Portugal. Subimos a la casa de una vecina que vivía en el último piso. La madona estaba casada con un alguacil que estaba enfermo. Se subió ella encima y estuvo en buena plática -que la tenía ella buena y mejor rostro-; echándola de menos el marido, y [viendo] que estaba arriba, teniéndoselo prohibido, llamó a una mulata que tenía, diciéndole que le abriese la puerta. Habló la mulata alto para que la escuchasen dónde quería ir:

- ¡Baja, bellaca, y tráeme las medias y los zapatos y dame acá la espada, que la he de matar, pues va sin mi licencia!;

porque parece que sin medias y zapatos no se podía hacer el sacrificio.

En fin, bajó ella muy disimulada con la almohada y nosotros hasta el pie de la escalera. Le abrió la mulata y yo, como no vi pólvora para mucho, me puse a echar un vistazo y oí que le dijo estas formales palabras:

- ¿Dónde vienes, bellaca? ¿No te mandé que no subieses arriba? ¿De qué te turbas, Isabel? Mira aquella boca desvergonzada y esos labios tan descoloridos y besados, como si hubieses tratado con algún lobo.

Ella, fingiendo indignación, dijo:

- ¡Desvergonzado, infame, que boca y pecho donde han cabido tales palabras bien merecía que se las hiciese verdaderas!; si tú fueras hombre, quitárasme la vida, pues tal pensabas, y no hablaras tales palabras de tu mujer, mas eres infame; por vida de mi madre que no he de dormir en esta casa; váyanme a llamar, y bájame mi cama abajo, que no he de quedar en esta casa.

Y con esto se bajó, riendo; y abrazando al otro, le dijo:

- Vaya, hermano, con Dios, y no se enoje, que ya esto queda templado, y ansí fuera la vuelta presto, como él me vendrá a rogar presto.

Tanta habilidad tienen éstas para sus enredos. Y así con razón decía Andrés de Macedo que a la sombra de la cruz que el marido hace cuando se bendice:

Ma chi del Canto mio piglia diletto,

un'altra volta ad ascoltarlo aspetto. 


\section{BIBLIOGRAFÍA CONSULTADA}

\section{Ediciones de Fastiginia}

Veiga, Thomé Pinheiro da (Turpin): Cervantes en Valladolid, o sea, descripción de un manuscrito inédito portugués intitulado "Memorias de la corte de España en 1605", existente en la Biblioteca del Museo Británico de Londres, ed. de Pascual de Gayangos: Revista de España, tomos 97-98; números de 25 de abril, 25 de mayo, 10 y 25 de junio y 10 de julio de 1884 .

VeIgA, Thomé Pinheiro da (Turpin): Fastigimia ou festas geniais, ed. de Aníbal Pereira de Sampaio Bruno, Porto, Collecção de Manuscriptos inéditos agora dados á estampa. III, Typ. Progresso, 1911. Reproducida en facsímil por la Imprensa Nacional-Casa da Moeda, con prefacio de Maria de Lurdes Belchior, 1988.

VEIGA, Tomé Pinheiro da (Turpin): Fastiginia o fastos geniales, trad. del portugués por Narciso Alonso Cortés. Prólogo de José Pereira de Sampaio, Valladolid, Imprenta del Colegio de Santiago, 1916 (se basa en la traducción que publicó anotada a partir del mes de marzo de 1913 en el Boletín de la Sociedad Castellana de Excursiones. Reeditada en Valladolid, Ayuntamiento de Valladolid, 1973). Reimpresa con el título de Fastiginia. Vida cotidiana en la corte de Valladolid, trad. y notas de Narciso Alonso Cortés, Valladolid, Fundación Municipal de Cultura, Ayuntamiento de Valladolid, Ámbito, 1989.

\section{Bibliografía secundaria}

Abreu, Maria Fernanda de: Cervantes no Romantismo Português. Cavaleiros andantes, manuscritos encontrados e gargalhadas moralíssimas. Dissertação de doutoramento em Literaturas Românicas Comparadas, apresentada à Universidade Nova de Lisboa em 1992, Lisboa, Editorial Estampa, 1994, pp. 63-77.

AlmeIDA, Isabel Adelaide Penha D. de Lima e: Livros portugueses de cavalarias, do renascimento ao manierismo, Lisboa, Universidade de Lisboa, 1998, pp. 70-71.

Barbosa, Elisabete: Tomé Pinheiro da Veiga. O Homem e o seu Tempo, Coimbra, Faculdade de Letras, 1966.

BARRETO, João Franco: Bibliotheca Lusitana: BNL, B 1206-1211, vol. III, fols. 451v-452r.

BRETSCHNEIDER, Andreas: El ingenioso hidalgo Don Quixote de la Mancha, cavallero de la triste figura (Leipzig, Henning Gross, 1614), Centro de Estudios Cervantinos y Armero Exposiciones y Ediciones, 2005.

Diccionario da Língua Portuguesa, Porto, Porto Editora, $1999^{8}$.

Díez Borque, José María: “1605: Vida y Literatura”, en Don Quijote, Madrid, 1605 (Imprenta, libros y lectura en la España Moderna), José Manuel Lucía Megías (ed.), Madrid, Ollero \& Ramos. En prensa en 2006.

Escudero, José Antonio (coord.): Los validos, Madrid, Editorial Dykinson, Universidad Rey Juan Carlos, 2004.

Ferreira, Vítor Vladimiro: "Tomé Pinheiro da Veiga, um português na corte de Valhadolide", Lisboa, Associação dos Arqueólogos Portugueses, 1988, pp. 49-89, en Sep. IV Centenário da morte de Frei Luís de Granada, 1988.

Lucía Megías, José Manuel: "Modelos iconográficos de El Quijote (siglos XVII-XVIII): I. Primeras notas teóricas", en Litterae, 2, 2002, pp. 59-103.

- "El manteamiento de Sancho Panza (I, XVII): lectura de un episodio cervantino a través de algunos de sus grabados", en Don Quijote Ilustrado. Don Quijote als Leser und die Spanische Renaissance. Edición de Javier Gómez-Montero, Inés M. Martín y José 
Ramón Trujillo, Christian-Albrechts Universität zu Kiel y Fugger Libros, 2003, pp. 77-96.

- "Modelos iconográficos del Quijote: siglos XVII-XIX (una primera aproximación a una herramienta de trabajo)", en Actas de las VIII Jornadas Asociación Española de Bibliografía, Madrid, 2004, pp. 103-131.

- Los primeros ilustradores del "Quijote”, Madrid, Ollero \& Ramos, 2005.

- y Aurelio VARGAS DÍAZ-TOLEDO: "Don Quijote en América: Pausa, 1607 (Facsímil y edición)", en la revista colombiana Literatura: teoría, historia y crítica, $\mathrm{n}^{\circ} 7$, 2005, pp. 203-244.

MACHADO, Diogo Barbosa: Bibliotheca Lusitana historica, critica e chronologica, etc., Lisboa Occidental, 1741- 1759, 4 vols. Coimbra, Atlântida Editora, 1965, vol. II, p. 156.

Martínez Hernández, Santiago: El Marqués de Velada y la corte en los reinados de Felipe II y Felipe III. Nobleza cortesana y cultura política en la España del Siglo de Oro, Salamanca, Junta de Castilla y León, 2004.

Martínez LóPEz, Enrique: "Duelos y quebrantos. Rebuznos de casta en un menú cervantino. Sobre los que con desazón comen "duelos y quebrantos los sábados" y los motejados de "cazoleros" o "berenjeneros", en Casa del tiempo, Universidad Autónoma de México, Vol. VII, Época III, n 83-84, dic. 2005-ene. 2006, pp. 84-93 (http://www.difusioncultural.uam.mx/casadeltiempo/83 dic ene 2005/).

Martins, Serafina Maria Grazina: A descrição na fastigimia de Tomé Pinheiro da Veiga [Texto policopiado]: representação do olhar, Lisboa, [s.n.], 1990.

Micó, José María (ed.): Orlando furioso, de Ludovico Ariosto, trad., introd., ed. y notas de José María Micó, Madrid, Espasa, Biblioteca de Literatura Universal, 2005.

Neves, Álvaro: "Tomé Pinheiro da Veiga e a Fastigimia", en Boletim Bibliográfico da Academia das Sciencias de Lisboa. Segunda Série, vol. I, Fasc. No 1, Outubro, 1911, Lisboa, Imprensa Nacional.

Perdigão, Leonor Ribeiro: A mulher em Fastigimia de Tomé Pinheiro da Veiga. Tese de Mestrado em Literatura Portuguesa apresentada à Faculdade de Letras da Universidade de Lisboa, Lisboa, [s.n.], 1990.

PÉrEZ y GonZÁlez, Felipe: "Don Quijote antes del Quijote", en La Ilustración Española y Americana, junio, julio y agosto, $\mathrm{n}^{\text {os }}$. 27-30, 1905.

Real ACAdemia Española: Diccionario de la Lengua Española, Madrid, Espasa, 2001, $22^{\mathrm{a}}$ ed.

RIVARA, Joaquim Heliodoro da Cunha: Catálogo dos manuscriptos da bibliotheca publica eborense, ordenado com as descripcões e notas do bibliothecario Joaquim Heliodoro da Cunha Rivara e com outras próprias, por Joaquim António de Sousa Telles de Matos, Lisboa, Imprensa Nacional, 1868, 4 vols.

Rivas HeRnánDEZ, Ascensión: Lecturas del Quijote (siglos XVII-XIX), Salamanca, Ediciones Colegio de España, 1998.

Rodrigues, Ernesto: Fastigínia: a carta interminável. Dissertação de Mestrado em Literatura Portuguesa, Lisboa, Faculdade de Letras, 1990.

- "Fastigínia: Elementos para uma edição crítica", en Românica. Homenagem a Maria de Lourdes Belchior, n 1-2, 1992-1993, pp. 49-54.

Silva, Inocêncio Francisco da: Dicionário Bibliografico Portuguez, Continuado por Brito Aranha, Lisboa, Imprensa Nacional, 1858-1894, 17 vols. 


\title{
Resumen
}

Desde la publicación de la primera parte del Quijote en 1605, el éxito de la obra se manifestó de diversas maneras, entre las que destaca la aparición de los protagonistas en espectáculos festivos y populares, incidiendo así en un determinado modo de recepción. De entre todos estos acontecimientos, nos hemos centrado en la Fastiginia, de Tomé Pinheiro da Veiga, un texto en el que se narran, como si de una crónica se tratara, las fiestas celebradas en Valladolid con motivo del nacimiento del futuro Felipe IV. Durante las mismas, en los días 10 y 28 de junio, tiene lugar la primera aparición documentada de la recepción de Quijote.

Palabras clave: Fastiginia. Tomé Pinheiro da Veiga. Quijote. Primera documentación de la recepción del Quijote.

\begin{abstract}
Since the publication of the first part of the Quixote in 1605, the success of the work emerged in different ways, among them stands out the release of the main characters in festive and popular spectacles, showing therefore a determinated way of acceptance. Among all these events we have studied on the Fastiginia, of Tomé Pinheiro da Veiga, a text that recounts, as if it were a cronicle, the festivities celebrated in Valladolid for the birth of the future Philip IV. During the 10 and 28 of june, takes part the first release documentated of the Quixote's reception.
\end{abstract}

Key words: Fastiginia. Tomé Pinheiro da Veiga. Quijote. First documentation of the Quixote's reception. 